\title{
EMPLOYMENT POLICIES: A LESSON FROM AMERICA
}

\section{Introduction}

The purpose of this article is to examine the controversy surrounding the means by which promises become binding in employment law. The dilemma is exposed in the decisions of the courts in Taylor v Secretary of State for Scotland. 1 The industrial tribunal and the Employment Appeal Tribunal were prepared to accept that entitlements could be created unilaterally: "( $t$ )he evidence was that.....changes and additions to prison officers' contracts were notified by circulars ..."2 In the House of Lords, adherence to the orthodox contractual model was so strong that their lordships felt that, in accepting the contractual status of the equal opportunities policy, they were obliged to invent a finding of fact that the notification was subsequent to a negotiated variation. 3 The absence of evidence of this assumed prior negotiation leaves exposed the de facto acknowledgment of unilateral creation of contractual entitlements. Such a development poses questions about the jurisprudential nature of promises in employment law and the rationale for their enforcement.

Taylor shows that English law may be ready to accept as contractual unreciprocated promises. This development will confront the courts with conflicting values: first, the value rooted in the necessity to establish an environment of orderly market transactions, in which certainty and fairness require the performance of a promise freely volunteered; and secondly the value rooted in the need to maximise the general welfare, which would permit management to modify or revoke strategic or tactical policy statements should business conditions so dictate. It will be argued that the jurisprudence of many of the state jurisdictions of the United States offers a more developed treatment of the enforcement of policies, and it suggests a possible means by which the power of managerial direction can be reconciled with the individualised version of justice which demands that a promise be performed.

1 [1997] IRLR 608, EAT; [1999] IRLR 363, Ct. of Sess.; [2000] IRLR 502, HL.

2 The EAT quoting from the decision of the industrial tribunal: [1997] IRLR 608 at p. 609.

3 [2000] IRLR 503 at p. 504. 
Managerial prerogative, which expresses the power of unilateral decision making, is central to the employment relationship. The duty to obey orders inherent in every contract of employment is an expression of the subjection of the employee to managerial control. Any legal obligation binding management to act subject to the prior consent of an employee arises only in so far as contract provides. In the absence of such contractual limitations managerial prerogative concerning the strategic and tactical direction of the business is, of course, untrammelled (except for statutory constraints). Changes to working practices, the amendment of promotion criteria, or the removal of non-contractual benefits, no matter how fundamental to the working experience and expectations of employees, can be effected by unilateral management action if they are outside the scope of the contract, and this is so even if the employees affected had been formally encouraged to expect the continuation of the status quo ante.

However, the increasing rigidification of the employment relationship has been an evident characteristic of recent common law jurisprudence. A common law extension of contractual entitlements has been associated with the significant expansion in implied terms, and in particular the implied duty to maintain trust and confidence. 4 This novel penetration of contract into the regulation of the working environment is substantially concerned with the promotion of the dignity of and respect for employees in the workplace and, less directly, with promoting efficiency through enhanced morale and lower staff turn-over 5 This judicial project also articulates a rejection of arbitrary, capricious, irrational or even inefficient management decision-making, which again signals an indirect concern

\footnotetext{
4 This is discussed by Brodie in The Heart of the Matter: Mutual Trust and Confidence (1996) 25 ILJ 121. He persuasively argues that the idea of trust and confidence is wider than the courts' rhetoric suggests. The terms implied in Goold (Pearmark) Ltd. v. McConnell [1995] IRLR 516 and Scally v. Southern Health and Services Board [1991] 4 All ER 563 perform a similar function to the duty to maintain trust and confidence since they demand that employees be treated with respect and dignity. These ideas are central to the trust and confidence duty. We have also argued elsewhere that trust and confidence already embraces some of the elements of a broader obligation to act in good faith: Hough and Spowart-Taylor, $A$ Common Law Agenda for Labour Law, [1999] Web Journal of Current Legal Issues, http://webjcli.ncl.ac.uk/1999/issue2/hough2.html.

5 Hough and Spowart-Taylor, loc. cit. These developments are not solely concerned with extending the common law protection of employees. Management's power to defeat industrial action regardless of the legitimacy or otherwise of the employees' claim has also been strengthened: Secretary of State v. ASLEF No.2 [1972] 2 All E. R. 949; Wiluszynski v. LB of Tower Hamlets [1989] ICR 493; BT v Ticehurst [1992] IRLR 219 .
} 
with enhanced management standards and more efficient enterprise 6 These developments suggest some judicial distaste for unbridled managerial power.

Thus, at the heart of the present debate concerning the scope of contract lie concerns about setting appropriate limits to managerial prerogative. It is in this context that the recent decision of the House of Lords in Taylor should be read. The implications of its decision pose the controversial question: how far will the courts curtail the employer's legitimate interest in modifying policy statements, codes of practice or other instruments for the guidance of decision makers, no matter what their nomenclature?

\section{Questions Posed by Taylor}

In Taylor an equal opportunities policy was held to be contractually binding, ostensibly on the grounds that notification of the policy promise was itself sufficient to create a binding obligation. This leaves many questions unanswered. The first relates to the nature of the obligation. A "policy" normally provides a commitment to a future course of behaviour identified from a number of possible alternatives. It is operated subject to the conditions that prevail or can be foreseen as likely to prevail at the time of its inception. The continuation of this factual context gives purpose to the policy; its absence renders the policy obsolete. This possibility of change in the underlying factual context suggests the fundamental objection to rigidifying policy documents and elevating them to fully contractual status. The global economic or commercial environment inherently poses for enterprise an evolving matrix of fiscal, monetary, supply, demand and profitability issues that mean that no policy guidance should be embedded beyond its commercially useful shelf-life. The Taylor decision that such policies can acquire contractual effects is made less compelling by its failure to propound any problem -solving device which might recognise not only the shifting demands of

\footnotetext{
${ }^{6}$ There are numerous decisions of which the following are examples: Associated Tyre $v$. Waterhouse [1976] IRLR 386; British Aircraft Corpn. v. Austin [1978] IRLR 332; Courtaulds Northern Textile v. Andrews [1979] IRLR 84; Hilton International Hotels (UK) Ltd v. Protopapa [1990] IRLR 317; Goold (Pearmark) v. McConnell [1995] IRLR 516; Smith v. Croft Inns Ltd. [1996] IRLR 84.
} 
managerial direction of the enterprise but also offer some protection of the entitlement created by the employer's representation.

However, not all policies are so dependent upon the flux of trade conditions and this must provide a caveat to any objections to a further rigidification of the relationship. Some policies merely express fundamental legal rights; only the detail of their implementation is vulnerable to change. An employer is not at liberty to revoke the obligation not to subject workers to unlawful discrimination, but may wish to alter, for example, the detail of the manner of implementation or the targets by which success would be judged. In contrast, revocation of a policy governing promotion criteria engages fewer legal rights than an equal opportunities policy. In essence there may be some fundamental standards which are right for permanent contractual status, whilst the case for other policy guidance is less convincing.

As we shall see, the United States courts have endeavoured to meet the objection that employers should not be tied to anachronistic policies whilst also developing some mechanisms to allow for the benefit formally held out by the employer to be enforced. So far, however, this radical jurisprudence has been ventured without the courts having reached an entirely cohesive doctrine. Taylor prompts an examination of the US experience to ask a number of fundamental questions: How are enforceable entitlements identified? Does any binding promise become a feature of the employee's contract that can be altered only bilaterally? Should the policy be regarded as revocable only with consent unless the employer has expressly reserved the power of unilateral revocation? Alternatively, does the contractual right attach to the policy only while the policy is in force, leaving the employer free to revoke it with or without notice? If unilateral revocation is possible, would the courts tolerate revocation on any grounds? Would it be tolerable to allow a cynical employer to suspend unilaterally a commitment formally offered in order that it could avoid the obligation it otherwise imposed only to re-impose it subsequently?

\footnotetext{
7 In relation to promotion an employee will have a right not to be treated arbitrarily or capriciously and to have the criteria fairly applied: Post Office v. Roberts [1980] IRLR 347.
} 
The "Handbook Exception" in the United States

Courts in the United States have confronted the enforcement of promises in the context of claims by employees to rebut the presumption that employment is 'at will'. In such cases the employee seeks to enforce a commitment often made in a formal policy statement, (perhaps a personnel manual or staff handbook) that the employer will dismiss only for cause (the so called 'handbook exception'). 9 In arriving at the same conclusion to that reached by the House of Lords in Taylor the Michigan Supreme Court in Toussaint v Blue Cross \& Blue Shield of Michigan 10 determined that such commitments could have contractual effects.11 It held that:

"1) a provision of an employment contract providing that an employee shall not be discharged except for cause is legally enforceable although the contract is not for a definite term, and

2) such a provision may become part of the contract either by express agreement .... or as a result of an employee's legitimate expectations grounded in an employer's policy statements" (emphasis supplied).

The second of these could suggest merely the waiver of the common law right to dismiss "at will". This is a very different matter from creating a general principle by which unilateral declarations of policy become contractual. However, the words "may become part of the contract" unequivocally conceptualise the handbook exception within contract and not estoppel. Thus, by its express terms, Toussaint allows enforceable entitlements to arise from unilateral managerial representations. In this regard the ratio of the decision is directed at

8 Employers at common law have a freedom to dismiss without notice and without cause: see further, Protecting At Will Employees Against Wrongful Discharge etc.,(1980) 93 Harvard Law Review 1816 and C. J. Peck, Unjust Discharges from Employment, (1979) 40 Ohio St. L.J. 1.

9 It is, of course, possible that employees will seek to assert other benefits promised in personnel manuals. These may be, for example, alleged contractual restrictions on dismissal: Morris v. Lutheran Medical Centre 215 Neb 677, guarantees as to disciplinary procedures or pre-dismissal procedures: King v. PYA/Monarch, Inc., 317 S.C. 385, 453 S.E.2d 885 (1995) or rules on holiday pay: Langdon v. Saga Corpn. 569 P $2 \mathrm{~d} 524$.

10292 N.W.2d 880, 408 Mich 579, (Mich.) 1980.

11 The court reasoned that the 'at-will' doctrine was merely a rule of construction and placed no limitation on the parties' freedom of contract: $292 \mathrm{NW} 2 \mathrm{~d}$ at p. 884 . The controversy concerns how contractual obligations are formed in the exercie of that freedom. 
the common experience of industrial relations that not all policy statements emerge from joint negotiating machinery, but instead from the unilateral expression of managerial control. However, if consideration may be regarded as the price of the promise, ${ }^{12}$ formal policy statements issued after the formation of the contract of employment appear to be gratuitous $\sqrt{13}$ How, after Toussaint, can their enforcement be explained? ${ }^{4}$

Four solutions to the problem of reconciling Toussaint with orthodox doctrine have been posed, although the Supreme Court of Michigan has had to concede that

12 Pollock, Principles of Contract, (13th edition) at p. 133, approved in Dunlop Pneumatic Tyre Co. Ltd. v. Selfridges Ltd. [1915] AC 847, at p. 855, per Lord Dunedin.

13 The ostensible absence of consideration has vexed the US courts as much as it ought to the English ones: see e.g., Swain v. West (Butchers) Ltd. [1936] 3 All ER 261; Skagerberg v. Blandin Paper Co ., 197 Minn. 291, 266 N.W. 872 (1936); Bussard v. College of St. Thomas, 294 Minn. 215, 200 N.W.2d 155 (1972).

14 The majority of other states also recognise a handbook exception: e.g., Hoffman-LaRoche Inc. $v$ Campbell 512 So 2d 725 (Ala 1987); Leikvold v Valley View Community Hosp 141 Ariz 544; 688 P.2d 170 (1984); Chambers $v$ Valley Nat'l Bank 3 IER Cases 1476 (Ariz 1988); Cleary v American Airlines 111 Cal App 3d 443; 168 Cal Rptr 722 (1980); Brooks v Trans World Airlines Inc. 574 F Supp 805 (D Colo 1983) (applying Colorado law); Continental Air Lines Inc. v Keenan 731 P.2d 708 (Colo 1987); Lincoln v Sterling Drug Inc. 622 F Supp 66 (D Conn 1985) (applying Connecticut law); Green v Howard Univ 134 U.S. App DC 81; 412 F2d 1128 (1969); Kinoshita v Canadian Pacific Airlines 724 P.2d 110 (Hawaii 1986); Watson v Idaho Falls Consolidated Hosp Inc. 111 Idaho 44; 720 P.2d 632 (1986); Duldulao v St Mary of Nazareth Hosp Ctr 115 Ill 2d 482; 505 NE2d 314 (1987); Allegri v Providence-St Margaret Health Ctr 9 Kan App 2d 659; 684 P.2d 1031 (1984); Wyman v Osteopathic Hosp of Maine Inc. 493 A2d 330 (Me 1985); Staggs v Blue Cross of Maryland Inc. 61 Md App 381; 486 A2d 798 (1985) cert den 303 Md 295; 493 A2d 349 (1985); Toussaint supra; Pine River State Bank v Mettille 333 NW2d 622 (Minn 1983); Morris v Lutheran Medical Ctr 215 Neb 677; 340 NW2d 388 (1983); Southwest Gas Corp v Ahmad 99 Nev 594; 668 P.2d 261 (1983); Woolley v Hoffman-LaRoche Inc. 99 NJ 284; 491 A2d 1257 (1985) modified on other grounds 101 NJ 10; 499 A2d 515 (1985); Forrester v Parker 93 NM 781; 606 P.2d 191 (1980); Weiner v McGraw-Hill Inc. 57 NY2d 458; 457 NYS2d 193; 443 NE2d 441 (1982). But see Sabetay v Sterling Drug Inc. 69 NY2d 329; 514 NYS2d 209; 506 NE2d 919 (1987); Bolling v Clevepak Corp 20 Ohio App 3d 113; 484 NE2d 1367 (1984); Smith v Teledyne Industries Inc. 578 F Supp 353 (ED Mich 1984) (applying Ohio law); Langdon v Saga Corp 569 P.2d 524 (Okla Ct App 1976) (severance pay); Vinyard $v$ King 728 F2d 428 (CA 10 1984) (applying Oklahoma law); Yartzoff v Democrat-Herald Publishing Co 281 Or 651; 576 P.2d 356 (1978); Wolk v Saks Fifth Ave 728 F2d 221 (CA 3 1984) (applying Pennsylvania law); Small v Springs Industries Inc. 292 SC 481; 357 SE2d 452 (1987); Osterkamp v Alkota Mfg Inc. 332 NW2d 275 (SD 1983); Hamby v Genesco Inc. 627 SW2d 373 (Tenn App 1981). But see Bringle v Methodist Hosp 701 SW2d 622 (Tenn App 1985); Smith v Kerrville Bus Co Inc. 709 F2d 914 (CA 5 1983) (applying Texas law). But see Reynolds Mfg Co v Mendoza 644 SW2d 536 (Tex Civ App 1982); Piacitelli v Southern Utah State College 636 P.2d 1063 (Utah 1981) (educational institutions); Sherman v Rutland Hosp 146 Vt 204; 500 A2d 230 (1985); Benoir v Ethan Allen Inc. $147 \mathrm{Vt}$ 268; 514 A2d 716 (1986); Barger v General Electric Co 599 F Supp 1154 (WD Va 1984) (applying Virginia law); Thompson v Kings Entertainment Co 653 F Supp 871 (ED Va 1987) (applying Virginia law); Thompson v St Regis Paper Co 102 Wash 2d 219; 685 P.2d 1081 (1984); Ferraro v Koelsch 124 Wis 2d 154; 368 NW2d 666 (1985); Mobil Coal Producing Inc. v Parks 704 P.2d 702 (Wyo 1985). 
'there is no clear consensus as to either the legal theory supporting the handbook exception or the scope of the exception.' 15

\section{(a) the unilateral contract}

Many states, of which Wisconsin 16 Minnesota 17 Oklahoma 18 Connecticut 19 (and, for a time, Arizona20) are but examples, regard the employment contract not as an ongoing contract but as a series of unilateral contracts. The employee accepts the employer's unilateral offer through their continued job performance. The new policy benefit is formally conceptualised as a unilateral offer that is communicated to the employee upon delivery of the new handbook or policy. Acceptance of the offered benefit by the employee occurs when they present themselves for work at the next opportunity. Consideration is identified in either the acceptance of continued employment by the employee or as the provision of further performance. 22

The conceptualisaton of the employment-at-will contract as a unilateral contract has been emphatically rejected by other states including Arizona, and doubted even in Michigan where it was seen as "strikingly artifical"23 In Demasse v. ITT Corpn.24 the Arizona Supreme Court indicated how vulnerable employees might be

15 In re Certified Question, Bankey v. Storer Broadcasting. Co 432 Mich 438, at pp. 448-449.

16 Ferraro v. Koelsch 124 Wis 2d 154, 368 N.W.2d 666 (1985).

17 Pine River State Bank v. Metille 333 NW2d 627 (1983).

18 Langdon v. Saga Corpn 569 P 2d 524.

19 Lincoln v Sterling Drug Inc. 622 F Supp 66 (D Conn 1985) (applying Connecticut law)

20 Chambers $v$ Valley National Bank 3 IER Cases 1476 (Ariz 1988).

21 See, e.g., Wagner v. City of Globe, 722 P. 2d 250, 253 (1986).

22 Under the first alternative the failure to exercise the option of resignation is consideration: Pine River State Bank v. Metille 333 NW2d 627 (Minn, 1983); in the second, it is the continued performance of the employee's duties: Langdon v. Saga Corpn. 569 P 2d 524.

23 In re Certified Question, Bankey v. Storer Broadcasting. Co 432 Mich 438 at p.447. The Supreme Court also reasoned that there will be doubts about when the act bargained for by the employer will be fully performed unless the "act" is simply a days work. The artifice is that few employers and employees begin each day contemplating fresh contractual negotiation.

${ }^{24}$ http://www.supreme.state.az.us/oop/qfullhit.htw?CiWebHitsFile=\%2Fopin\%2Fpdf99\%2Fcv970177\%2Ep $\mathrm{df} \&$ CiRestriction $=$ Demasse $\&$ CiBeginHilite $=\% 3$ Cstrong + class $\% 3$ DHit $\% 3 \mathrm{E} \&$ CiEndHilite $=\% 3 \mathrm{C} \% 2$ Fstrong \%3E\&CiUserParam3=/query.asp\&CiHiliteType=Full (1999) 
if such a model were adopted because it would mean that any entitlement the employee had secured could be erased overnight. It stated in effect that it was absurd to hold that employees who presented themselves for work the day following the purported revocation of their contracts by the employer "would manifest assent, constitute consideration, and permit cancellation of any employment rights to which they were contractually entitled".5 If it were so, any rights created by the handbook exception would be illusory. The Supreme Court of Michigan has also doubted whether unilateral contract adequately explains the ruling in Toussaint.26

\section{(b) Reliance theory}

Reliance theory provides an alternative explanation of contractual liability to that of bargain theory. The difficulty is that bargain theory fails to bind promisors to formally volunteered but unreciprocated undertakings even where the promisee has relied upon the promise. It offends one conception of justice if a promisor can resile at will from a formal promise. This is especially so where the promise is made in the course of a commercial relationship, a fortiori where the promisee has reasonably relied upon the promise. Such a difficulty invites a re-evaluation of the theoretical rationale for the enforcement of promises by resort to a reliance model. According to one reading of Toussaint this explains the decision of the Michigan Supreme Court to found liability, inter alia, upon a legitimate expectation The promise of job security is not purchased by the furnishing of additional consideration by the employee because the duties of his or her post are likely to remain unaltered. The promise generates a legitimate expectation of performance because it represents a formal commitment to the employee that inherently invites the employee to rely on it 27 Thus reliance theory does not shrink from the unilateral creation of binding entitlements. Indeed in some states, such as Arizona,

\footnotetext{
25 Ibid.

26 In re Certified Question, Bankey v. Storer Broadcasting. Co 432 Mich 438 (Mich:1989).

27 Note, however, that in Toussaint, 408 Mich 579 at p. 613, the Supreme Court declined to hold that Tousaint was required to adduce evidence of reliance. Further, the court identified an enhancement in the employment relationship to the benefit of the employer who chooses to make promises in policies. This finding hints at the existence of consideration as an explanation of the enforcement of the policy, but the judgment does not state this explicitly. It does, however, obscure the theoretical foundation on the decision in Toussaint.
} 
the handbook exception is explicitly explained in terms of reliance theory, although at a practical level the extent to which detrimental reliance is required is uncertain.8 However, reliance theory is not universally accepted; some courts instinctively adhere to bilateral explanations of contractual liability. As we shall see below, state courts in Michigan have endeavoured to modify the doctrine of consideration rather than to abandon it.

\section{(c) Bargain Theory Re-Evaluated: Practical Benefit}

Bargain theory places a value on reciprocity and holds that enforcement is justified where performance has been purchased at the price of the promise. In Re Certified Question, Bankey v. Storer Broadcasting. Co 29 the Michigan the Supreme Court has adopted the technique of finding consideration in the practical benefit which employers derive from issuing policies which formally promise benefits to employees. 0 In this decsion the practical benefit was identified as follows:

The employer secures an orderly co-operative and loyal work force and the employee the peace of mind associated with job security and the conviction that he will be treated fairly. 31

This reasoning was not innovative in Michigan for a similar approach can be identified in the much earlier decision in Psutka v Michigan Alkali Co. 32 In this case it was held that an enforceable right to claim death benefit was created even

28 Leikvold v. Valley View Community Hosp 141 Ariz 544 (1984); but see also Ferraro v. Koelsch 124 Wis 2d 154, 368 N.W.2d 666 (1985). In Re Certified Question, Bankey v. Storer Broadcasting. Co. 432 Mich 438, at p. 449 footnote 13 the court also explained Wyman v Osteopathic Hosp. of Maine Inc. 493 A2d 330 (Me 1985), Sherman v Rutland Hos. 146 Vt 204; 500 A2d 230 (1985)Vinyard v. King 728 F2d 428 (CA 10 1984), and Morris v Lutheran Medical Ctr. 215 Neb 677; 340 NW2d 388 (1983) as founded on reliance theory.

29432 Mich 438; 443 N.W.2d 112. (Mich. 1989)

$30 I d$. although if consideration is present, it is unclear as to how this can be reconciled with the decision in Toussaint that liability is explained inter alia on the grounds of a legitimate expectation. An even more radical approach is to hold that consideration is but an evidentiary requirement imposing a burden which parties can satisfy with alternative evidence of mutual consent: Pine River State Bank v. Metille 333 NW2d 627 (Minn, 1983).

31443 N.W.2d 112, 138-139, (Mich. 1989). See also Langdon v. Saga Corpn 569 P 2d 524.

32264 N.W. 385 (1936) 
though the pension and death benefit plan stated that it was a purely voluntary provision and constituted no contact and conferred no legal right on any employee. This was so because '(a)mple consideration to support the death benefit plan as a contract with the employees is found in the attraction of more competent workmen, the inducement of better and more continuous service, and the avoidance of the expense of labour turn-over.'

By this modified version of bargain the offer of a benefit, even in a policy statement, can be supported by consideration. Although it professes loyalty to bilateralism, this only applies at formal level. The practical benefit contemplated is not actually 'bargained for exchange, ' nor is it the 'price of the promise' 33 This expanded version of the doctrine of consideration only thinly disguises an acceptance of the unilateral creation of contractual entitlements.

(d) Obligations within the penumbra of contract.

A more innovative theoretical foundation of the handbook exception also lies in both Toussaint and In re Certified Question, Bankey v. Storer Broadcasting. Co In these cases the court alternatively declared that the exception is not established by any of the traditional means of forming contracts. 34 Instead contractual obligations are created from a source that is merely 'instinct with obligation'. The obligation so described seems to be one that has many of the characteristics of contract, especially in the manner of in which it takes effect, but its creation is novel.

The benefit to the employer of promoting .... an environment (enhanced by commitments to the employee) rather than the traditional contract-forming mechanisms of mutual assent or individual detrimental reliance gives rise to a situation "instinct with an obligation." 35

\footnotetext{
33 Pollock, loc. cit.

34 This was also buttressed in Toussaint by the ruling that there need be no negotiation of the policy in order for it to bind; indeed it was unimportant that the employee was ignorant of the policy: see below n. 36 .

35 Id. at 447-448. This explanation was was followed inter alia in Bullock $v$ Automobile Club of Michigan, 432 Mich 472, 480; 444 NW2d 114 (1989). and has recently been affirmed in the judgment of the Michigan Court of Appeals in Betts v. Butterworth Hospital Dec 17th 1999, http://www.michbar.org/opinions/
} 
The ambiguity of this instinctively recognised obligation appears to confuse an 'ought' with an 'is'. It signals a policy preference for binding employers even if orthodox principles cannot be stretched sufficiently to provide a clear doctrinal basis for doing so.

\section{(e) Summary.}

The State jurisdictions have yet to explain satisfactorily the doctrinal basis for the handbook exception. We have seen that at least four rival theories co-exist within the jurisprudence. However, we shall also see that in identifying particular promises within policy statements for enforcement the courts arguably favour the reliance model.

The probable conclusion from the substance of this doctrinal experimentation is that it legitimates the unilateral creation of rights and that this in substance flows through each of the four alternative models. It is explicitly so in the cases of the unilateral theorists, as well as some versions of reliance theory, and the penumbra theory. The expanded version of consideration professes bilateralism but within a version of contract in which bilateral negotiation and a 'meeting of minds' is conspicuously absent. .66 If unilateral creation is acknowledged, how may the entitlement so created be modified or extinguished? This will be considered below.

\section{The theoretical foundation of enforcement in English law.}

As in the United States, a significant objection to the enforcement of benefits extended to employees through policy statements is that they ostensibly appear to lack mutuality, which raises the possibility that the promise to confer the benefit is nudum pactum. A full analysis of the developments in English jurisprudence falls

\footnotetext{
36 For an employment policy to bind it was held that "(n)o pre-employment negotiations need take place and the parties' minds need not meet on the subject; nor does it matter that the employee knows nothing of the particulars of the employer's policies.....," Toussaint, 408 Mich 579 at p. 613. The possibility of creating unnegotiated entitlements was also accepted in Bullock v. Automobile Club of Michigan, 432 Mich 472, 480 (1989) and followed in Betts v. Butterworth Hospital Kent Circuit Court, Dec 17th 1999, see note 35 above.
} 
beyond the scope of this article. However, a distinction should be made between the example of the employee who accepts an offer of employment after the policy has been promulgated and that of the employee who is confronted by a policy subsequent to the contract of employment. In the former case there is no objection to enforcing any "apt" commitment made in the policy since the employee has furnished consideration for it just as for any other benefit offered by the employer. It is different in the case of the employee whose contract is concluded prior to the introduction of the new policy because in the absence of some reciprocal exchange the promise to confer the benefit is ostensibly gratuitous. ${ }^{77}$

In summary, the answer to this objection is that the courts have, in English employment law, broadened the concept of valid consideration. In doing so they have constructed a version of consideration that is strikingly similar to that of the third technique (bargain theory/practical benefit) adopted by the US courts. Employers who extend benefits to employees in formal policy statements do so in pursuit of self-interest and not for altruistic reasons. Indirect benefits flowing from the enhancement of the employment relationship include the expectation on the part of the employer of lower staff turnover and higher staff morale where employees believe that they are treated fairly and valued. The recent decision of the Court of Appeal in Edmonds $v$ Lawson, 88 confirms this shift in English jurisprudence in deciding that an unremunerated pupil barrister has a contractual relationship with her chambers, the consideration for which lies in the benefit the chambers acquires from attracting talented pupils. This is not an unexpected development after Williams $v$ Roffey Bros. Ltd 39, a fortiori in a context in which a significant value is attached to continuing the relationship between the parties. It is also consistent with a version of consideration articulated by Corbin who argued that consideration 'need not be the object of the promisor's desire for which he offers his promise in exchange, but may instead be an action or forbearance by the promisee as a result or natural consequence of the promise. All that is required is there that there should, between the promise and the consideration, be a causal connection':40

37 Swain v West (Butchers) Ltd. [1936] 3 All ER 261.

38 [2000] IRLR 319 CA.

39 [1990] 2 WLR 1153.

40 A L Corbin, Does a Pre-Existing Duty Defeat Consideration?-Recent Noteworthy Decisions, 27 Yale L.J. 362, 366. 
In sum the revised version of the doctrine of consideration permits the enforcement of entitlements contained in formal policy statements. The subsequent issue is to identify which entitlements the courts will enforce?

\section{Identifying an enforceable entitlement}

It has already been observed that a policy is normally regarded as a flexible framework for operational guidance; by its very nature it lacks the characteristic of permanence. But Taylor and Toussaint hold that policy commitments can become permanent components of the contract of employment. Which entitlements are suitable for such treatment?

If there is an appropriate analogy with collective agreements, the courts will incorporate into contracts those entitlements that are 'apt' for incorporation. 41 However, such a test merely poses the further question of what makes an entitlement 'apt' for elevation to contract?

In the United States the jurisprudence is in a more developed condition in the context of the handbook exception. A promise "apt" for incorporation into the contract is one which generates a legitimate expectation. Toussaint, and the subsequent decision in Rood $v$. General Dynamics Corp. 22 decide that this conclusion derives from a two stage process. There must be a consideration of what the employer has promised and whether that promise was reasonably capable of creating a legitimate expectation of the entitlement claimed. In Rood the court defined a promise as a manifestation of intention to act or refrain from acting in a specified way, so made as to justify the promisee in understanding that a commitment has been made 43 Hence it is the objective commitment made to the employee which is the sine qua non of enforcement. If the employer retains a

\footnotetext{
41 Alexander v. Standard Telephones and Cables plc [1990] ICR 291 upon which reliance was placed in Wandsworth $L B C \vee D^{\prime}$ Silva, see n. 56 below.

42444 Mich. 107 (Mich. 1993).

43 See also Adkins v. American Axle \& Manufacturing Inc., Wayne Circuit Court, Aug 31999 http://www.michbar.org/opinions/
} 
choice whether or not to act in a specified way, no promise is created. ${ }_{44}^{4}$ Policy statements and, especially, oral statements, have to offer a "clear and unequivocal" statement of job security 45 A high degree of 'specificity' is required. ${ }^{16}$ The more indefinite the terms of a policy or statement, the less likely it will be that the employer will be found to have made a promise to the employee 47 Statements which have an aspirational quality, such as "an expression of an optimistic hope of a long relationship" 48 will not create a contractual obligation. This strikes a parallel with English law, most noteably Grant where the judge justified non-enforcement of an equal opportunities policy inter alia on the grounds that it was "idealistic". 99 Additionally, in the US a specific disclaimer in the policy statement that no enforceable rights are to be created is conclusive proof that a commitment sufficient to sustain a legitimate expectation was absent. 0

\section{The treatment of policies in English law.}

The limited English jurisprudence on the enforcement of policies substitutes 'intention' for the US standard of 'commitment'. The difference is that 'intention' invokes the traditional bilateralism of the mutual meeting of minds and thus differs markedly from the unilateralism of 'commitment'. Since intention must be ascertained by objective means the courts look for evidence other than the employer's subjective motivation. Evidence of objective intention can be found not only in the language of the putative policy obligation but also in the manner in which the policy was promulgated. Grant $v S W$ Trains Ltd 51 concerned the

\footnotetext{
44 Rood v. General Dynamics Corp., 444 Mich. 107, at pp.138-139.

45 American Axle, http://www.michbar.org/opinions/ Highstone v Westin August 9th 1999, http://www.michbar.org/opinions/

46 Highstone, id. Note a parallel development in English law in English v. Unison Rhyll County Court case MA810294, IDS Brief 668, Sept. 2000 where a provision in a "guide" given to a member on joining the union created a contractual entitlement because of, inter alia, the certainty of the language. This expressly referred to a "right" having been created.

47 See for example, American Axle http://www.michbar.org/opinions/, following Rood 444 Mich. 107 at p. 139.

48 Rowe v. Montgomery Ward \& Co., 437 Mich. 627, 473 N.W.2d 268, 273-75 (Mich. 1991); Highstone v. Westin August 9th 1999 http://www.michbar.org/opinions/

49 Grant v. SW Trains Ltd.at [1998] IRLR 188 at p. 189.

50 Lytle v. Malady, 579 N.W.2d 906 (Mich. 1998).

51 [1998] IRLR 188.
} 
unsuccessful attempt to enforce an equal opportunities policy containing an express commitment by the employer not to discriminate on the grounds of sexual orientation. The court identified the absence of the necessary intention as the key factor in denying the liability of the employer ${ }^{52}$ This absence was identified by an examination of: (i) the process by which the document was promulgated; (ii) the language in which the possible obligations were framed; (iii) the formal status of the document; and (iv) the relationship of the possible obligations with the express terms of the contract. These tests closely mirror the approach in the United States. However, the weight to be attached to them is markedly different. In Grant Curtis $\mathrm{J}$. was much influenced by the status of the document in which the alleged promise was enshrined. As this was clearly a policy document, he found that this was of itself incompatible with the intention to create legal relations. In the United States this is not a conclusive factor, nor one which appears to receive much weight. The more significant criterion is whether, notwithstanding its formal status, the employer can be understood to have made the necessary commitment to the employee.

But this did not conclude the matter because his lordship continued to consider the language in which the parties' actual intention was expressed, and found the putative obligation expressed as a "concession" in "very general, even idealistic terms". 53 The emphasis upon 'concession' signals a disinclination to bind an employer to unbargained for promises and seems to draw upon a classical version of consideration which the Court of Appeal abandoned in Edmonds v Lawson 54 This also signals a more conservative approach than has been evident in the United States.

In Grant his lordship also considered the manner in which the policy had been promulgated within the employer's organisational structure. Because such obligations usually emanated from a joint negotiating machinery and not from the

\footnotetext{
52 However, there would presumably be a contractual duty to apply a policy consistently; any failure in this regard might breach the implied duty to maintain trust and confidence: Gardner v Beresford [1978] IRLR 63.

53 The policy stated, inter alia, "We are committed to ensuring that all individuals are treated fairly and are valued irrespective of disability, race, gender, health, social class, sexual preference, marital status, nationality, religion, employment status, age, or membership or non-membership of a trade union."

54 [2000] IRLR 319 CA.
} 
employer acting outside that machinery there was found to be further evidence that promissory intention was absent. This also reflects a strong preference for a bilateral model where obligations result from some process of offer and acceptance. This is another feature of the judgment that has been abandoned in the United States. Finally his lordship examined other promises as indicators of the intended meaning of the policy. He found that the policy conflicted with the express words of the contract of employment. Loyal in this regard to classical theory, he concluded that any implied term (sic) could not prevail over a conflicting express term. The possibility of variation was not accepted.

In sum, whilst Grant, in examining the question of intention, appears to draw upon factors similar to the Michigan authorities, it betrays a radically different and more traditional approach. There is an instinctive trust in bilateralism and a sub silentio concern about the absence of consideration. In refusing to go beyond the formal character of the document his lordship was obviously reluctant to convert a policy statement, the very idea of which is infused with a lack of permanence and, hence, a power to revoke, into a fixed component of the employees' contracts of employment. But in doing so the court arguably gave insufficient weight to the point that the employer had manifestly made a formal commitment to equal opportunities which it had not chosen to revoke. In other words the judge may have been influenced to deny contractual status to the policy simply through a desire to preserve the power to revoke or amend and did not give sufficient weight to the argument that the employer could be bound by a promise which it had not actually revoked or amended. In refusing to consider this point Grant in effect treated the promissory words as illusory.

In Wandsworth LBC $v D^{\prime}$ Silvd 55 the dispute concerned the employer's decision to reduce the period of sickness absence before which a review of an absence record was triggered. In contrast to Grant, the court was less influenced by the source of the alleged obligation (an internal 'code of practice') and placed a greater emphasis not only upon the language in which it was expressed but also the industrial context in which the policy would operate. Its introductory paragraph described the code as a "framework" for the guidance of managers. The code continued to state

55 [1998] IRLR 193. 
that discussions over sickness absence between management and sick employees were an industrial desideratum and acknowledged that flexibility is required in dealing with the divergent range of circumstances surrounding sickness absence. The Court concluded that good industrial practice would regard those parts of the statement affecting reviews of absence to be unenforceable. Supervisors were not being directed as to what was contractually obliged to happen in dealing with sickness cases; $\sqrt[56]{ }$ instead the code provided guidance encapsulating a desirable choice of possible conduct which itself would ensure that in the range of different circumstances surrounding sickness absence there was room for compassion as well as rigour. This is consistent with US jurisprudence in which the retention by the employer of a discretion as to outcomes negates the creation of an enforceable right.77 However, counsel conceded that the parts of the code which dealt with appeals were binding, inter alia, because the code described these as 'appeal rights'. This also reveals the emphasis that the language of the code received in the Court of Appeal.

The decision of the House of Lords in Taylor provides no further guidance as to the approach of the English courts. After losing the point before the EAT, the employer in the Court of Session conceded that the policy was contractual, and in the House of Lords the case was resolved simply by construing the contract. Their lordships were not required to address the complex issues which follow from the conclusion that the policy created a contractual right.

In conclusion, in seeking to identify contractually binding promises the English courts, in contrast to those in the US, seek to identify the mutual intention of the parties rather than the narrower issue of whether an objective commitment has been made by the employer. The fact that the alleged obligation emanates from a policy rather than a source having more obvious contractual potentia 58 seems (if Grant is good law) to weigh heavily against contractual status because the

\footnotetext{
56 The court stated that good industrial practice required a more sophisticated analysis than the invocation of penalties after a given number of days' absence. For example, an employee claiming to be ill and absent for one day who was found shopping in a town centre should be treated differently than an asthma sufferer genuinely absent for a number of days. The need to preserve this flexibility was a powerful argument against finding that the provisions had contractual effects.

57 Rood v. General Dynamics Corp., 444 Mich. 107.

58 Such as a collective agreement.
} 
judiciary appear to be troubled by rigidifying what might properly be described as operational guidance rather than a permanent undertaking. There is evidence of an adherence both to a bilateral model as well as an instinctive reaction against enforcing promises for which there appears to be no direct quid pro quo ('concessions').

In contrast in the US the absence of direct exchange does not preclude a promise made in a policy statement from having contractual effect. Moreover, the source of the obligation is treated as subordinate to the question of whether the employer was making a commitment to act or refrain from acting in a specific way thereafter. If in Grant the court had focused upon the clear commitment made by any employer who takes the formal step of declaring an equal opportunities policy, it is possible that the decision might have been different. Admittedly the reasoning in D'Silva more closely resembles that in the United States in the emphasis it places on the language of the document; but the negotiated origins of the code in D'Silva clothed it in a bilateralism which removed some of the concerns expressed in Grant. Had the code been issued unilaterally it is possible that the concession regarding even appellate 'rights' would not have been made since the ostensible absence of consideration might have placed the case in a closer relationship with Grant. One reading of D'Silva thus supports the argument that English courts remain more likely to enforce appropriate parts of bilateral rather than unilateral instruments.

\section{What entitlement derives from an enforceable policy statement?}

If the courts find that a commitment made in a policy statement does have contractual status, what effect does this have? The possible choices are that the employer may modify or revoke: at will, with notice, with notice only on specified grounds, or only with the employee's consent. So far the English courts have not been required to address this question. 
At the heart of the problem lies the tension between rights and efficiency. To what extent, if at all, can these divergent policy imperatives be reconciled?

In the United States in the context of the handbook exception this issue has been the subject of much debate. It is proposed to examine below the two contrasting models that have emerged from the jurisprudence. The first derives from Michigan, and has been dubbed "the administrative model" 59 the second results from a decision of the Supreme Court of Arizona that adopts a more orthodox bilateral model. These two models have been chosen because in substance they identify the fundamental choice which the English courts may confront.

At the heart of the problem which each jurisdiction has had to address lies the uncertain jurisprudential basis of the handbook exception in the Toussaint case. This is of central importance to the question of revocation or modification of the policy because there is a logical argument that, if the obligation is unilaterally created, revocation could also be possible as a unilateral exercise of managerial power, whereas bilateralism would insist on modification only with consent. It is also, in the context of reliance theory, unclear what the legitimate expectation is.

What entitlement derives from it? In particular, is it an entitlement that trumps efficiency in all circumstances?

It is true that most states have a handbook exception similar to that in Toussaint. They accept that a commitment made to the workforce in a staff handbook or policy statement can give rise to a contract. As indicated above there is little theoretical agreement as to how this is so. Accordingly, on the vital questions touching upon the amendment or revocation of the policy the jurisdictions of the various states diverge. In Michigan the Supreme Court has come to recognise, as did his lordship in Grant, that efficiency arguments weigh heavily against locating policies and statements, no matter how formally and sincerely they express a commitment to the employees, within a traditional and fixed contractual environment. The argument which favoured the creation of an individualised entitlement upon which an employee could insist even in the face of a legitimate

59 H. H. Perritt Jnr, Employee Dismissal Law and Practice, § 4.44 (3d ed. 1992). 
business interest was outweighed by the opposite view that an entitlement should not become a permanent feature of the employment contract modifiable only after successful negotiation with each individual employee ${ }^{60}$ Employers should not be tied in perpetuity to anachronistic policies, nor should they be forced to operate a variety of different policies which must inevitably result if each individual employee had the right to veto change: some might consent to change, others would not, and employers would find themselves in a confusingly complex position as they became obligated in different ways to the respective members of the workforce. But the court also recognised that employers who freely choose to issue policy commitments do create legitimate expectations of performance and, under Toussaint, these can become contractual. Given that this is so, how could those entitlements be modified or rescinded except by bilateral means?

The Supreme Court of Michigan has endeavoured to address this conundrum by interpreting the concept of the legitimate expectation that Toussaint introduced. It decided that any legitimate expectation deriving from a non-permanent policy was not an expectation that the policy should last indefinitely, nor that it should be immutable. Three principles were therefore constructed in Re Certified Question, Bankey v Storer Broadcasting. Co:

(i) because a policy with no fixed duration cannot be expected to endure perpetually, the employer must have (under the power of managerial direction) the implied right to rescind or modify the policy. This means that the employer must abide by its terms only whilst the policy is in force 61 The legitimate expectation is that the policy will be applied consistently and fairly throughout its duration. The practical consequence is that where an employer has chosen voluntarily to issue a commitment to the employees the employees have a contractual right to expect performance of that obligation until the policy is revoked or varied. The second principle is a consequence of the first;

60 In re Certified Question, Bankey v Storer Broadcasting. Co. 443 N.W.2d 112, 138-139, (Mich. 1989)

61 Note that in this respect the court was following its earlier obiter opinion in Toussaint at pp.614-615 that the right of unilateral modification applies even if the policy entitlement is contractual. However Toussaint stipulated that notice would not be required. 
(ii) after serving reasonable notice the employer retains the power either to revoke or to modify the policy unilaterally. This may be done without reserving an express power to do so in the terms of the policy itself although such an option remains open to the employer;

(iii) the third principle rejects an unfettered power to revoke or vary policies which otherwise create rights. The court will not countenance revocation in bad faith. This means that the employer can revoke only in pursuit of legitimate business reasons, although the scope of this is uncertain 62 However, this limitation has signalled at least a minimum substantive duty to act fairly.

The third principle is intended to address cynical evasion or manipulation of the implied right of amendment or revocation. This was necessary because the Supreme Court was aware of the obvious loop-hole that (i) and (ii) together created. In an extreme case the cynical employer could have revoked the promise of job security, dismissed an employee without cause immediately afterwards only to re-instate the policy once the employee had cleared their desk and left the premises. Accordingly, the court imposed safeguards intended to restrict the employer's power to misuse the managerial prerogative that principle preserved.

In conclusion, the Michigan solution departs from the absolute all-or-nothing approach of Grant which holds that managerial power can only be preserved by denying contractual effects to the policy. Michigan states that the policy binds while it is in force but the employer, after reasonable notice, has a power of unilateral modification or revocation. The service of notice affords the employees process rights, and the restriction on the employer acting in bad faith allows the court at least some minimum substantive control against abusive manipulation of managerial powers. In effect, Michigan recognises management's claim for directorial bureaucratic power, but it sees no reason why this should not be tempered with a respect, albeit somewhat limited, for individual rights.

62 It is not clear whether, for example, this burden is discharged by the honest belief that the change is commercially desirable, or a more objective assessment that revocation would in fact generate a commercial advantage. 
However, the Michigan approach is not universally supported. The Supreme Court of Arizona recently rejected any doctrine of unilateral modification of contractual entitlements.33 It adhered strictly to orthodox principles by holding that for any modification or revocation of a policy binding under Toussaint there must be "(1) an offer to modify the contract, (2) assent to or acceptance of that offer, and (3) consideration. Continued employment after the issue of the replacement policy would not furnish sufficient consideration." The Supreme Court emphasised the point further:

"Consideration will be found when an employer and its employees have made a "bargained for exchange to support [the employees'] . . . relinquishment of the protections they are entitled to under the existing contract." 64

It reasoned that the administrative model pursued in Bankey was unsatisfactory because employees wishing to preserve their legal rights after receiving notice of a proposed unilateral change in their contracts would have no option but to resign.

Employers wishing to avoid the consequences of Toussaint were held to have a duty to protect their own interests by inserting an express reservation that no contractual rights were created. This possibility was held to afford employers sufficient protection enabling them to avoid being tied to outmoded policies. The employer who omits to do so was found to induce reliance on the terms of the policy and could not thereafter revoke or modify it by unilateral means.

The essential difference between the "administrative model" in Bankey and the orthodoxy of Demasse is that in the latter the employee acquires a substantive entitlement to the performance of the contractual obligation. The Arizona model demonstrates a greater concern with security of the "transaction" than that in Michigan. It respects the consequences of the bilateral model which is that the employee has a right to withhold consent to rescission or modification of the

\footnotetext{
${ }^{63}$ Demasse v ITT Corporation, above n.24. This was so even though the entitlement was created unilaterally.

64 Demasse, above n.24, citing Doyle v. Holy Cross Hosp., 682 N. E. 2d 68, 72 (Ill. App. 1997), aff'd 708 N. E. 2d 1140, 1999 WL 77557 (Ill.).
} 
policy. This means that the relevant parts of the policy can become a permanent component of the contract of employment. In contrast, in Bankey the emphasis is upon bureaucratic process rather than substantive entitlements: the employer can merely revoke the policy for bona fide reasons after service of reasonable notice.

Demasse and Bankey fundamentally delineate the dilemma that may come to face the English courts: does the employer have a limited power of unilateral modification or not? The alternatives available to English courts are substantially presented in the Michigan and Arizona jurisprudence. What would the effect be in English law if the courts were to follow either of those alternatives?

\section{Foreshadowing Developments in the English Common Law.}

If the English common law developed in a manner similar to the Arizona model, it would mean that orthodox principles of the law of contract would govern policy benefits incorporated into the contract of employment. Unless the employer adopted the straightforward expedient of reserving an express power to do so in the terms of the policy, it could not be varied or revoked without the consent of the individual employee. This possible development has actually been predicted by developments in the implied term of trust and confidence. In French v. Barclays Bank pld 65 the revocation of a promise that a discretionary bridging loan should be interest free was a breach of contract as conduct likely to destroy trust and confidence.

This means that, if, in English law, an employer breached the binding terms of the policy the employee could elect to treat the contract as continuing and sue for damages representing the value of the lost benefit, 66 or elect to terminate the contract and sue for damages for breach or unfair dismissal. If the benefit

65 [1998] IRLR 646.

66 Rigby v. Ferodo Ltd. [1987] IRLR 516. 
unilaterally revoked related to wages a claim would lie to an employment tribunal under Part II of the Employment Rights Act 1996.77

In contrast, the Michigan administrative model would endow the policy with contractual effects only until the expiry of the employer's lawful notice to amend or rescind it. During the policy's life the common law remedies would be available for breach, but after the service of notice the entitlement would evaporate. The only caveat might be that if the employer acted in bad faith there could be an independent action for a breach of the implied duty to maintain trust and confidence. An employee wishing to preserve his or her rights under the contract would be forced to resign before the employer's notice had taken effect and to bring an action for damages at common law. However, this remedy would normally be of little value since the damages would be limited to wages that would have been paid during the period of contractual notice.

However, this does not conclude the issue because repudiatory breaches of contract are also mediated as claims for unfair constructive dismissal. It is argued that, regardless of which alternative the English courts adopt, the practical differences in the protection afforded to employees in this respect will be slight. This is so because of the superiority of process over substantive rights in the English law of unfair dismissal. Even if the courts adopted the Arizona model, with its emphasis upon contractual rights, the English employee would, nevertheless, be vulnerable to their unilateral revocation. This is so because there are slender substantive limitations on when contractual rights can be overridden; the real protection for employees lies in the process rights afforded by unfair dismissal. This predominance of procedural over substantive controls, although derived from statute, closely resembles the Michigan administrative model.

67 By Employment Right Act 1996, s.27 "wages" are defined, inter alia, to mean "any sums payable to the worker in connection with his employment, including-

(a) any fee, bonus, commission, holiday pay or other emolument referable to his employment, whether payable under his contract or otherwise". The italicised words (emphasis supplied) indicate that a claim will lie to an Employment Tribunal in respect of wages or benefits promised in a policy statement or handbook even if the promise is found to be non-contractual. 
The provision in the Employment Rights Act 1996, s. 98 (1) (b) that the employer may justify a dismissal for "some other substantial reason" (SOSR) makes significant concessions to managerial prerogative and subordinates contractual entitlements. For example, the employer who can demonstrate that a decision to dismiss (constructively) was reasonable will have dismissed fairly notwithstanding that the employee is simply insisting on the terms of the contract.68 The requirement of reasonableness is satisfied where the employer acts within the "band of reasonable responses" which a reasonable employer might have adopted 60 A finding that the employer has repudiated the contract becomes a meaningless victory for the employee should the employer demonstrate that it has behaved reasonably and for legitimate business reasons. This substantially recalls the Michigan jurisprudence that also subordinates contractual rights to unilateral modification for bona fide business reasons.

In English law occasional experiments with enhanced substantive controls, such as the requirement to demonstrate that the survival of the business was at issue before a modification in contract was enforced by dismissal 70 have not rooted successfully. The very limited substantive limitations on the power to act in breach of contract are that employers must not impose change for arbitrary reasons, 11 and they must demonstrate some actual and immediate business need for the change 72 However, even this possibility is somewhat weakened by the subjective standard by which the business case for change is judged: it is, in other words, a matter for the employer's honest belief that advantages to the business will accrue, and not a matter for the court to examine objectively. 3

As in Michigan, the essence of the balance between efficiency and rights lies in safeguards of a limited procedural rather than a substantive kind. The employee should be given notice of the proposed change in the contract and should be

\footnotetext{
68 Farrant v. The Woodroffe School [1998] IRLR 176 EAT.

69 Post Office v. Foley; HSBC Bank plc (formerly) Midland Bank v. Madden [2000] IRLR 827 CA; Iceland Frozen Foods v. Jones [1983] ICR 17; Richmond Engineering v. Pearce [1985] IRLR 79.

70 An argument which succeeded before an Industrial Tribunal in Catamaran Cruisers Ltd $v$ Williams but was overruled by the EAT [1994] IRLR 386.

71 Catamaran Cruisers v. Williams, id.

72 Evans v Elemeta Holdings [1982] ICR 323

73 Hannam v. TNT IPEC (UK) Ltd [1986] IRLR 165, at pp 167-8.
} 
informed that failure to accept the change will lead to dismissal. ${ }^{74}$ Time for reflection will also be weighed in assessment of the fairness or reasonableness of the employer's actions. 55

\section{Possible developments}

It is possible that English courts might enhance the substantive controls to protect the beneficiary of unilateral promises. The platform for this may prove to be the implied duty to maintain trust and confidence, the potential for which has already been illustrated in French. However, this Court of Appeal decision decided that, on the particular facts, revocation was a breach of the implied term; it did not decide that the implied term would preclude revocation in all circumstances; but, when weighing managerial interests in securing change and the employee's reliance on a formal promise it signals that significant weight will be attached to the latter. Indeed there are earlier dicta that reliance on a promise can, of itself, be overriding. 66

If English law chooses to develop the concept of a legitimate expectation, it may be forced to distinguish some promises from others. We have already argued that the exigencies of business might afford a more persuasive case for amending or revoking those policies that are inherently temporary. We argued that a policy governing promotion criteria is more easily tied to its underpinning but transient factual context than an equal opportunities policy which expresses values transcending the shifting demands of the market place. A legitimate expectation to continuation of the former type of policy could not reasonably be sustained where its underlying rationale had disappeared. But the rationale for equal opportunities is not so vulnerable to change.

A distinction between revocation and revision could be significant. Amendment of the policy might be more acceptable if the replacement policy respected the "core" value of non-discrimination. In essence, the scrutiny of rationality in this

\footnotetext{
74 RSC v. Irwin [1973] ICR 535; Bowater Containers Ltd. v. McCormack [1980] IRLR 50.

75 Bowater Containers Ltd. v. McCormack, id.

76 Jones v. Lee \& Guilding [1980] IRLR 67, per Lord Denning MR at p.69, although the promise was not made binding by means of the implied duty to maintain trust and confidence.
} 
context depends only on refinement of existing principles: a greater emphasis upon objectivity combined with a judicial commitment to examine whether the expectation of certain treatment may have a continuing legitimacy which in fairness outweighs the new policy choice which threatens to frustrate it.

\section{Conclusion}

The protection of entitlements in employment policies poses most acutely the divergent imperatives of preserving, on the one hand, managerial prerogative and, on the other, a respect for fairness, reliance and the security of promises. The English courts have responded to this by upholding one or other of these fundamental but competing sets of values without, as yet, a developed project to reconcile them. The jurisprudence of the state jurisdictions in the United States offers a more sustained and sophisticated analysis than has yet resulted in English law although a consistent doctrine has yet to emerge. The Toussaint exception is an interesting acknowledgment that the reality in the employment relationship is not a bilateral one: the content of the contract is in many respects itself a product of managerial prerogative rather than the 'at-arms-length' bilateralism found in transactional contracts. Toussaint offers an alternative explanation of the enforcement of promises which is fundamentally rooted in a theory of reliance and not bargain. The Arizona and Michigan models each allow employers to preserve a power to modify or revoke the policy: in the case of Arizona this is by purely formal means of incorporating a reservation clause into the policy itself; in Michigan this is unnecessary for the power to revoke is inherent in the transitory quality of the policy itself. The difference between them is that the Arizona model forces the employer, who has not reserved the appropriate power, to secure change only by consent. In Michigan change can be achieved by procedural means.

It has been argued that, if English law developed according to either one of these two models, the result at least in the context of dismissal would not differ. The SOSR category of permissible dismissals ensures that even fully-fledged contractual rights (the Arizona model) are subordinated to managerial direction subject only to procedural protections and the limited substantive ones which 
closely echo those adopted in Michigan. But the courts, either on the basis of further developments in trust and confidence, or the idea of a legitimate expectation, might develop the already-existing but minimal substantive controls to scrutinise whether a policy commitment has a continuing legitimacy which survives the employer's claim that business reasons should frustrate it.

Professor Barry Hough,

Law School, Southampton Institute.

Ann Spowart-Taylor

Principal Lecturer in Law, Business School, University of Sunderland. 